\title{
Fungsi Kesantunan Berbahasa pada Kegiatan Musyawarah
}

\author{
Destrianika Binoto $^{1}$, Suparno $^{1}$, Anang Santoso ${ }^{1}$ \\ ${ }^{1}$ Pendidikan Bahasa Indonesia-Universitas Negeri Malang
}

\begin{tabular}{l}
\hline INFO ARTIKEL \\
\hline Riwayat Artikel: \\
Diterima: $14-08-2019$ \\
Disetujui: $11-03-2020$ \\
\hline
\end{tabular}

\section{Kata kunci:}

politeness in language; politeness function; deliberation activities; kesantunan berbahasa; fungsi kesantunan; kegiatan musyawarah

\begin{abstract}
This study aims to describe the politeness of the language function in the activities of deliberation in the village of Tarohan. The method used in the form of a recording method in the form of tapping techniques to analyze data. The recording method in the form of tapping technique is used to record data in a clandestine way that is not visible or without the knowledge that will be recorded in the data analysis process. the function of politeness in language lies in stating information, declaring agreements, stating decisions, stating information, expressing congratulations, requesting recognition, asking for information, asking for reasons, asking for opinions, asking for sincerity, ordering, banning, apologizing, and criticizing.
\end{abstract}

ABSTRAK

\begin{abstract}
Abstrak: Penelitian ini bertujuan untuk mendeskipsikan fungsi kesantunan berbahasa pada kegiatan musyawarah di desa Tarohan. Metode yang digunakan berupa metode rekam berupa teknik sadap untuk menganalisis data. Metode rekam berupa teknik sadap ini digunakan untuk merekam data dengan cara sembunyi-sembunyi yang tidak terlihat atau tanpa sepengetahuan yang akan direkam pada proses analisis data. Fungsi kesantunan berbahasa terdapat pada menyatakan informasi, menyatakan perjanjian, menyatakan keputusan, menyatakan keterangan, menyatakan selamat, meminta pengakuan, meminta keterangan, meminta alasan, meminta pendapat, meminta kesungguhan, menyuruh, melarang, meminta maaf, dan mengeritik.
\end{abstract}

\author{
Alamat Korespondensi: \\ Destrianika Binoto \\ Pendidikan Bahasa Indonesia \\ Universitas Negeri Malang \\ Jalan Semarang 5 Malang \\ E-mail: destrianika@gmail.com
}

Bahasa memegang peran penting bagi suatu bangsa dengan bahasa maka suatu bangsa dapat mengenalkan identitas diri yang menunjukkan jati diri bangsa itu. Bahasa pula memiliki peran penting dalam berkomunikasi antara sesama manusia dalam kehidupan sosialnya. Manusia memakai bahasa untuk dapat membangun, berbicara, berkomunikasi, berhubungan dan bekerjasama dengan sesamanya. Setiap komunikasi antara sesama manusia memiliki hubungan, kerja sama, perasaan baik secara langsung maupun tidak langsung dengan cara berkomunikasi. Komunikasi antara sesama akan terjalin jika komunikasi tersebut bersifat santun.

Kesantunan berbahasa pada setiap daerah memiliki perbedaan tergantung dari norma sosial yang berlaku. Kesantunan berbahasa memiliki ciri sikap santun atau menghormati sesama petutur untuk terjalin komunikasi yang baik. Artinya, pemakaian kesantunan berbahasa dalam proses percakapan sangat penting karena dapat menujukkan sikap saling menghormati dan menghargai yang dapat diwujudkan melalui solidaritas dan kekeluargaan yang mempunyai aturan-aturan yang berlaku antara penutur dan mitra tutur pada daerah tempat tinggalnya. Berbicara tentang kesantunan berbahasa tidak akan habishabisnya untuk dibahas oleh setiap orang, baik yang berpendidikan maupun tidak berpendidikan. Seseorang dapat dikatakan mempunyai moral apabila cara bertuturnya santun terhadap mitra bicaranya. Kesantunan berbahasa dalam lingkungan formal maupun nonformal sangat penting untuk dilaksanakan karena semuanya bersumber dari cara bertutur. Tuturan bukan hanya alat untuk menentukan seseorang santun, tetapi tingkah laku juga menggambarkan santun. Tingkah laku merupakan identitas atau kepribadian yang menggambarkan sifat dan etika dalam bertutur dengan sesamanya. Menurut (Gunawan \& Qaimuddin, 2014) pada kesantunan dalam berbahasa tidak hanya mengucapkan kata terima kasih, apa kabar, dan maaf, tetapi harus mengetahui budaya dan nilai-nilai yang terdapat pada masyarakat tutur.

Fungsi kesantunan berbahasa terdapat pada tuturan penutur hal ini sejalan dengan pendapat (Chaer, 2012) menjelaskan bahwa fungsi kesantunan yang utama adalah dari pihak penutur. Artinya, fungsi dari pihak penutur merupakan patokan atau acuan dalam menentukkan kesantunan berbahasa. Fungsi-fungsi tersebut dapat diteliti pada kegiatan apa saja lebih khususnya kegiatan musyawarah yang dilaksanakan di desa dengan tujuan mengetetahui seberapa banyak fungsi kesantunan berbahasa yang dipakai. Pertimbangan dasar sebagai patokan pentingnya penelitian ini adalah penelitian ini dilakukan untuk mendeskripsikan kesantunan berbahasa yang dilakukan oleh masyarakat desa Tarohan pada kegiatan musyawarah dengan memakai satu fokus penelitian sebagai patokan yang ditemukan 14 fungsi kesantunan berbahasa yang digunakan. 


\section{METODE}

Penelitian ini dikategorikan sebagai penelitian kualitatif dengan jenis fenomologis berlandaskan sosiopragmatik. Lokasi penelitian ini berada di desa Tarohan Kecamatan Beo Selatan Kabupaten Kepulauan Talaud Sulawesi Utara. Data dalam penilitian ini adalah data verbal satuan tuturan dalam interaksi antar penutur yang berkandungan nilai kesantunan. Sumber data dalam penelitian ini adalah teks tuturan semiformal yang terjadi dalam interaksi antar penutur yang berkandungan nilai kesantunan pada kegiatan musyawarah di desa Tarohan. Pengumpulan sumber data dalam penelitian ini menggunakan teknik rekam yaitu sadap untuk merekam secara diam-diam proses petuturan dalam kegiatan musyawarah dan teknik transkrip kemudian pengumpulan data dalam penelitian ini menggunakan teknik elisitasi data, teknik catatan lapangan, dan teknik wawancara. Analisis data penelitian ini dilakukan melalui empat tahapan, yaitu klasifikasi data, pengodean data, penyajian data, dan penarikan kesimpulan.

\section{HASIL}

Berdasarkan hasil analisis data didapatkan ada 29 fungsi kesantunan yang ditemukan pada proses kegiatan musyawarah di desa Tarohan Kabupaten Kepulauan Talaud. Masing-masing data akan diuraikan sebagai berikut. Berdasarakan hasil analisis data dapat dijelaskan bahwa fungsi kesantunan berbahasa terdiri atas menyatakan informasi, menyatakan perjanjian, menyatakan keputusan, menyatakan keterangan, menyatakan selamat, meminta pengakuan, meminta keterangan, meminta alasan, meminta pendapat, meminta kesungguhan, menyuruh, melarang, meminta maaf, mengeritik.

\section{Fungsi Kesantunan Berbahasa pada Rapat Musyawarah}

Kesantunan berbahasa ini didasarkan pada prinsip kesantunan yang dicetuskan oleh Leech dengan teori mengenai sejumlah maksim dan di kolaborasikan dalam beberapa fungsi kesantunan yang didalamnya terdapat bermacam-macam maksim. Pada saat pelaksanaan kegiatan musyawarah ini penggunaan bahasa Indonesia jarang digunakan karena pengguna bahasa di tempat penelitian menggunakan dialek melayu Manado dan dialek Talaud karena itu sudah menjadi kebiasaan dan merupakan bahasa yang dipakai sehari-hari.

\section{Fungsi menyatakan informasi pada rapat musyawarah}

Rapat musyawarah pada masyarakat desa Tarohan menjadi saluran untuk masyarakat dapat memberikan masukan dan saran terlebih kritikan kepada pemerintah desa dalam kemajuan perkembangan desa. Informasi ini dapat disampaikan pada penyampaian pra pelaksanaan dana desa tahap I dan juga pemilihan anggota BPD yang baru yang akan disampaikan oleh bapak Kepala Desa dan ketua BPD yang lama selaku pemerintah desa untuk mempertanggung-jawababkan kegiatan desa selama periode yang telah ditentukan.

Konteks: pada kegiatan musyawarah pada saat itu yaitu pemberitahuan mengenai pemilihan BPD yang baru oleh ketua BPD yang lama)

\section{Data 1}

Bapak ketua BPD yang lama: (1) terima kasih atas kesempatan yang sudah dipercayakan oleh masyarakat dengan menunjuk saya sebagai ketua BPD Tarohan dan pada saat ini kita tahu pada hari ini itu berdasarkan pengumuman dari pemerintah Desa, yang sudah diumukan tadi malam dan tadi pagi bahwa pada hari ini kita akan melaksanakan musyawarah desa tentang pelaksanaan dana desa yang akan sudah diterima oleh Pemerintah Desa pada pagi hari ini. (FKMI1)

\section{Data 2}

Bapak Ketua BPD yang lama: dan pada hari ini juga kita akan menetapkan tentang pemilihan BPD yang baru, sebab batas dari kami sebagai BPD, cukup sampai bulan ini. (FKMI2)

Fungsi kesantunan yang menyatakan informasi memiliki indikator yang bersifat memberitahukan keadaan dan bermodus tuturan deklaratif. Pada rapat kegiatan musyawarah ini kesantunan yang menyatakan informasi melibatkan tuturan yang disampaikan oleh BPD yang lama yang menyatakan pada data (1) menyampaikan informasi dengan maksud masyarakat yang mengikuti rapat mengetahui tentang pelaksanaan dana desa dengan kalimat yang bersifat memberikan informasi.

Data (2) menginformasikan kepada masyarakat desa bahwa akan diadakan pemilihan BPD yang baru dan juga masa jabatan dari BPD yang lama hampir selesai. Kegiatan musyawarah di desa Tarohan yang dilaksanakan oleh Pemerintah desa semata-mata untuk kemajuan desa sehingga pemerintah desa mengadakan rapat tersebut. Fungsi kesantunan yang menyatakan informasi ini melibatkan pemerintah desa dan masyarakat dengan pembahasan dana desa dan pemilihan BPD yang baru di desa, sehingga sebelum diawali kepala desa memberikan arahan mengenai dana desa maka, bapak BPD yang lama diberikan kesempatan untuk memberikan arahan terlebih dahulu. Kesantunan yang terjadi pada fungsi menyatakan informasi sebenarnya adalah fungsi kesantunan yang sifat secara langsung, tetapi dalam konteks memberitahukan informasi mengenai materi yang akan disampaikan sebentar, bagi masyarakat Talaud menyampaikan informasi secara langsung merupakan hal yang biasa atau sesuai dengan kebudayaan yang ada di tempat itu sehingga terkesan santun. Menurut (Wijayanto, 2014) Sikap tidak santun itu terjadi bukan karena kalimat atau perkataan tertentu, melainkan ketidakcocokan dalam penggunaan ujaran dengan norma sosial 
suatu masyarakat tertentu. Hal tersebut juga diungkapkan oleh (Locher, 2006) mengatakan bahwa santun dan tidak santunnya sebuah petuturan tergantung dari pemakaian penutur yang sesuai dengan norma sosial tempat tinggalnya. Jadi, fungsi kesantunan yang menyatakan informasi pada proses petuturan di desa Tarohan antara penutur dan mitra tutur terjalin dengan baik karena berdasarkan pada norma sosial yang berlaku di wilayah tersebut.

\section{Fungsi menyatakan perjanjian pada rapat musyawarah}

Fungsi kesantunan berbahasa yang menyatakan perjanjian bersifat menyetujui suatu hal, seperti pada rapat musyawarah yang diadakan didesa Tarohan selain Kepala Desa menyampaikan pemberitahuan mengenai BPD yang baru juga melibatkan pendamping desa selaku penasihat desa yang memberikan masukan mengenai perencanaan dan desa yang akan digunakan untuk jalan produksi dan jalan desa yang sebagaimana telah disampaikan oleh Kepala Desa sehingga menimbulkan fungsi kesantunan yang menyatakan perjanjian.

Konteks: Pendamping Desa menyampaikan pendapat, masukan, dan kritikan kepada Kepala Desa dan pendapat kepada Desa mengenai BPD yang lama

\section{Data 3}

Pendamping Desa: Aahh yang terakhir pengadaan lokasi pembuangan sampah saya setuju dengan pendapat pak Kades tapi saran saja yahh pak Kades kita harus berani mengambil resiko dengan pengadaan ini menggunakan dan desa, ada beberapa desa yang lain dapat menggunakan dana desa untuk membeli tanah (FKMP1)

\section{Data 4}

Kepala Desa: Karena di minggu pertama itu, harus dituntut untuk pelaksanaan pelantikan BPD baru dibulan berikut sehingga petunjuk dari Bapak Camat mengeluarkan surat keputusan kepala Desa walaupun diatas 60 Tahun khususnya bidang Adat dan itu saya sudah komunikasikan dengan BPM karena tidak bisa dipungkuri bahwa sudah dua kali pembukaan sampai hari ini tidak ada orang dapat memenuhi persyaratan, jadi saya kira ini bisa dimalkumi bersama, ini jelas. (FKMP2)

Konsep kesantunan berbahasa yang menyatakan keputusan kegiatan musyawarah pada data (3) menjelaskan bahwa pendamping desa menyetujui hal mengenai pendapat Kepala Desa tentang alokasi pembuangan sampah dan juga memberikan saran untuk kemajuan pemerintah desa untuk lebih berani mengambil keputusan tentang hal itu yang memberikan gambaran bahwa hal menyatakan keputusan tergambar pada kalimat "saya setuju" dan "saran saja" yahh Pak Kades mewakili perkataan pendamping desa pada fungsi kesantunan menyatakan keputusan. Data (3) menunjukkan maksim kerendahan hati yaitu maksim ini menuntut penutur yaitu pendamping desa tidak menyombongkan diri melainkan meminimalkan rasa hormat pada diri sendiri dengan cara setuju dengan pendapat kepala desa dan memakai kata saran untuk menambahkan kesantunan dalam proses petuturannya sehingga terlihat santun saat berucap. Menurut (Ekawati, 2018) maksim kerendahan hati atau kemuarahan hati menuntut penutur bersikap rendah hati kepada orang yang biasanya disampaikan dalam tuturan asertif dan ekspresif.

Data (4) mendeskripsikan tentang masalah yang terjadi mengenai pemilihan BPD yang baru yaitu pada bidang adat, sebab sampai pada penetapan BPD yang baru belum ada calon yang memenuhi persyaratan yang telah diatur oleh panitia pemilihan dan kendala yang lain yaitu tidak ada orang yang mau mendaftar pada bagian bidang adat karna tidak menguasai adat, sehingga pemerintah desa selaku Kepala Desa mengambil kebijakan dengan pihak Kecamatan dan bagian BPM mengenai permasalahan itu dan Kepala Desa menyetujui kebijakan tersebut dan memberitahukan kepada masyarakat yang mengikuti rapat musyawarah pada saat itu. Data (4) dikategorikan dalam fungsi kesantunan menyatakan perjanjian karena bersifat pernyataan persetujuan dan menambahkan kalimat "jadi saya kira bisa dimaklumi bersama, ini jelas" sebagai penanda kesantunan yang lain.

\section{Fungsi menyatakan keputusan pada rapat musyawarah}

Fungsi kesantunan dengan menyatakan keputusan ini dilakukan oleh Kepala Desa dengan mempertimbangkan berbagai pendapat dari beberapa masyarakat yang bertanya mengenai pelaksanaan dana desa menyangkut pembuatan jalan produksi dan jalan desa. Petuturan yang terjadi antara bapak Tumpil sebagai masyarakat dan bapak Kepala Desa ini menimbulkan keputusan dan pertimbangan dalam kegiatan musyawarah ini.

Konteks: Pertanyaan dari salah satu masyarakat kepada Kepala Desa

Data 5

Bapak tumpil: boleh? (dengan mengacungkan tangan kepada KADES) Yaahah terima kasih, jadi kebutulan juga saya sebagai anggota panitia dan kami sangat takut jika melihat keadaan yang sekarang kan?? (dengan nada bertanya) tinggal disepakati saja, ini tinggal memilih dan menetukan ini siapa yang akan di adat? Entah orang tua siapa yang akan ditentukan dalam bagian adat jadi, kebetualn disini ada bapak Yunus ada bapak Lumendang dan bapak Mayuntu jadi mereka itu jago-jago (menguasai) dalam bagian adat jadi tinggal menunggu keputusan kita bersama agar bapak kepala Desa dapat membuat keputusan apa memang kita ini mengucapkan kata sepakat hari ini!! 
Data 6

Bapak kades: jadi, kita sepakat kalau bapak Yohanes Mayuntu sekalipun umurnya dia atas 60 Tahun tetap kita pakai saya akan mengeluarkan surat keputusan kepala desa dan lampirannya daftar hadir dan berita acara sehingga jika ada omongan dari di luar kita sudah memiliki bukti. (FKMKEP)

Fungsi kesantunan berbahasa dengan menyatakan keputusan pada data (5) mendeskripsikan sikap santun yang mempertimbangkan sesuatu hal yang sedang dilakukan oleh Bapak Tumpil selaku masyarakat pada tuturan verbalnya mengenai pemilihan bidang adat memakai kalimat jadi tinggal menunggu keputusan kita bersama agar bapak Kepala desa dapat membuat keputusan sebagai penanda tuturan deklaratif yang bermodus maksim kebijaksanaan hal ini sejalan dengan pendapat (Sari, 2014) maksim kebijaksanaan bersifat tuturan komisif dan impositif dan memaksimalkan keuntungan bagi orang lain.

Data (6) mendeksripsikan tentang fungsi menyatakan keputusan dengan memakai kata sepakat dengan menggunakan maksim kedermawanan hal ini sesuai dengan pendapat dari (Nurjamily, 2015) menjelaskan bahwa maksim penghargaan atau pujian dalam proses petuturan akan dianggap santun apabila memberikan penghargaan kepada pihak yang lain seperti yang dilakukan oleh Kepala Desa dengan memutuskan bahwa Bapak Mayuntulah yang menjadi kandidat bidang adat dengan menjawab pernyataan dari salah satu masyarakat sebagai wujud kesantunan berbahasa dalam proses kegiatan musyawarah. Ini menggambarkan bahwa dalam fungsi kesantunan menyatakan keputusan bersifat memberikan putusan pada suatu hal seperti yang sudah dilakukan oleh kepala desa sebagai penutur melakukan suatu keputusan terhadap mitra tutur yaitu Bapak Mayuntu dengan memberikan keuntungan kepada mitra tutur.

\section{Fungsi menyatakan penjelasan pada rapat musyawarah}

Fungsi kesantunan berbahasa dengan menyatakan penjelasan dilakukan dengan cara memutuskan suatu hal atau memberikan pertimbangan. Pada kegiatan musyawarah di desa Tarohan ini sebenarnya banyak penjelasan mengenai dana desa yang disampaikan oleh Kepala Desa mengenai pengelolaan dana desa dalam pembuatan jalan produksi dan jalan desa sehingga banyak putusan dari baik dari pemerintah desa dan juga masyarakat mengenai progam desa yang dibahas pada saat itu.

Konteks: Penjelasan mengenai dana desa oleh Kepala Desa dan tambahan dari Pendamping Desa

Data 7

Kepala Desa: dalam pembuatan jalan desa ini memerlukan material lokal, material lokal diantara pasir, kerikil dan batu, pasir, kerikil dan batu hari ini saya berani mengambil keputusan untuk kerikil harganya saya naikan 350 ribu per kubik jadi untuk kerikil catat ini 350 perkubik angkat ditempat untuk kerikil kemudian yang kedua pasir antar ditempat 250 ribu perkubik disana pembuatan jalan karena dalam kontruksi pembuatannya memerlukan batu disamping kiri dan kanan jalan. (FSMKET1)

Fungsi kesantunan berbahasa dengan menyatakan keterangan atau penjelasan mengenai sesuatu hal, telah ditemukan pada data (7) kegiatan rapat musyawarah di desa Tarohan dengan penjelasan mengenai material untuk pembuatan jalan produksi dan jalan desa telah diputuskan oleh Kepala Desa dengan kalimat "saya berani mengambil keputusan untuk kerikil harganya naik" sehingga ini dinyatakan sebagai kata menyatakan keterangan karena menerangkan bahwa harga material sebelumnya rendah dinaikan oleh Kepala Desa dengan membuat masyarakat antusias untuk bekerja dan data (7) menggunakan dua kata "saya berani" sebagai kalimat yang menegaskan bahwa kalimat ini terlihat menyakinkan yang bersifat santun untuk memperkecil potensi konflik dengan cara menyenangkan muka mitra tutur. Menurut Musyafir (2017) tujuan kesantunan menjadikan suasana percakapan menyenangkan, tidak mengancam muka mitra tutur dan efektif.

\section{Fungsi kesantunan menyatakan selamat pada rapat musyawarah}

Fungsi kesantunan menyatakan selamat mengandung pengertian ucapan selamat baik dalam keadaan senang maupun sedih, disertai dengan gerak mimik wajah yang menggambarkan keadaan ucapan tersebut. Pada kegiatan musyawarah di desa Tarohan fungsi kesantunan yang menyatakan selamat ditemukan pada ucapan yang terlontar dari mulut Kepala Desa dan Pendamping Desa disertai dengan senyuman dan kata selamat.

Konteks: Pendamping Desa mengucapkan selamat kepada BPD yang baru terpilih

Data 8

Kepala Desa: saya juga berterima kasih kepada diakhir periode bapak Yunus Sumalea sudah memberikan hibah kepada desa dengan ukuran 5 meter kali 15 untuk pembuatan jalan desa ini jadi, saya selaku pemerintah desa berterima kasih kepada bapak sekalipun tidak lagi menjabat lagi tetapi masih berkeinginan untuk membangun kampung saya atas pemerintah saya mengampresiasi hal tersebut.

Data 9

Pendamping Desa: selamat yah atas terpilihnya BPD yang baru dan selamat menjalankan program desa bersama pemerintah desa. 
Kegiatan musyawarah yang diadakan oleh Pemerintah desa untuk pelaksanaan dana desa dan juga pemilihan BPD yang baru ini, dapat ditemukan dua data fungsi kesantunan dengan menyatakan selamat yakni data (8) kepala desa berterima kasih kepada bapak Yunus yang telah memberikan tanahnya untuk pedambangunan jalan desa ini merupakan wujud ucapan selamat yang disertai dengan mimik wajah gembira sebab telah dilakukan pemberian tanah sehingga ini dapat digolongkan sebagai fungsi kesantunan dengan menyatakan selamat.

Data (9) pendamping desa memberikan selamat kepada BPD yang baru ini juga dapat digolongkan sebagai fungsi kesantunan menyatakan selamat karena menggunakan kata ucapan selamat dengan menggunakan tuturan deklaratif yang santun untuk mitra tutur dan memakai mimik wajah yang gembira sebagai ungkapan bentuk nonverbal untuk mendukung fungsi kesantunan menyatakan selamat. Hal tersebut sejalan dengan pendapat (Saputry, 2016) sikap santun juga dapat berwujud nonverbal seperti gerak-gerik atau gestur.

\section{Fungsi kesantunan meminta pengakuan pada rapat musyawarah}

Fungsi kesantunan meminta pengakuan memiliki indikator meminta jawaban dari mitra tutur dalam bentuk "ya" atau "tidak" dan "ya" atau "bukan" dengan menunjukkan kepastian bahwa setuju dengan pengakuan tersebut, sehingga pada kegiatan musyarah di desa Tarohan dapat ditemukan ada satu data yang menggambarkan meminta pengakuan yang dilakukan oleh salah satu masyarakat yang memotong pembicaraan dari kepala desa yang memberikan arahan.

Konteks: keadaan dimana Kepala Desa sedang menyampaikan materi dan ada salah astu masyarakat yang memotong pembicaraan

Data 10

Kepala Desa: kemudian PMT Posiandu dengan alokasi dana 32 juta jadi catatan kepada kader makanan setidaknya sekali-sekali daging ini kepala desa sudah naikan biayanya dan saya mohon makanannya ditambahkan

Masyarakat: (memotong pembicaraan dari Kepala Desa) jadi dalam setahun itu yah?

Kepala Desa: (menjawab pertanyaan dari masyarakat) iya dalam setahun 32 juta, jadi hitungan bukan hanya makanan saja tetapi yang membuatn makanan atau pemasaknya juga ada anggaran yang telah ditambahkan di dalamnya jadi diharapkan kepada saudarasaudara kader minum dan makanannya tolong diperbaiki!

Fungsi kesantunan menyatakan keputusan memiliki pemahaman untuk menyenangkan wajah mitra tutur dengan menggunakan bahasa yang santun seperti pada data (10) ditemukan kepala Desa sebagai mitra tutur, sedangkan masyarakat sebagai penutur sehingga untuk peristiwa tutur tersebut merupakan hal yang sudah biasa karena mitra tutur tidak merasa dirugikan sebaliknya mita tutur menghargai pertanyaan dengan menjawab "iya" untuk menerangkan kembali apa yang sedang dipaparkan oleh mitra tutur atau kepala desa sehingga ini tergolong pada fungsi kesantunan menyatakan keputusan. Menurut (Feeney \& Bonnefon, 2013) mengatakan bahwa penutur dapat meminimalkan ancaman dari mitra tutur dengan cara bersikap sopan dalam membalas ucapan dari mitra tutur.

\section{Fungsi kesantunan meminta keterangan pada rapat musyawarah}

Fungsi kesantunan berbahasa yang meminta keterangan bersifat uraian terhadap suatu hal dengan menggunakan kata tanya "apa" untuk benda, kata tanya "siapa" untuk orang, kata tanya "berapa" untuk jumlah, kata tanya "dimana" untuk tempat, dan kata tanya "kapan: untuk waktu. Fungsi menyatakan keterangan pada rapat musyawarah ini dituturkan oleh Bapak Pendamping desa dan bapak sekretaris BPD yang lama dalam hal mempertanyakan tentang program desa yang sementara dibahas oleh Kepala Desa.

Konteks: pertanyaan dari bapak Pendamping Desa dan bapak Sekretaris BPD yang lama kepada bapak Kepala Desa

Data 11

Pertanyaan dari Pendamping Desa

- Jadi untuk HOG disitu tidak disampaikan apakah harian itu atau borongan ini yang perlu dijelaskan! (FSMKET1)

Data 12

- $\quad$ Tidak disebutkan jumlah berapa kebutuhannya jangan samapai semua orang berkubik kelebihan! (FSMKET2)

Data 13

- Kapan akan dimulai atau besok bisa dimulai atau bulan juli pak Kades! (FSMKET3)

Data 14

Pertanyaan dari Sekretaris BPD yang lama

- $\quad$ Siapakah yang mewakili adat menurut Kades dan panitia pemilihan BPD ini? (FSMKET4)

Data 15

- $\quad$ Tetapi jika batu karang dimanakah letak yang bisa diambil batu itu! (FSMKET5)

Pertanyaan dari pendamping Desa dan Sekretaris desa ini dapat ditemukan lima jenis indikator fungsi kesantunan yang meminta keterangan. 
Data (11) menyatakan keterangan “apakah” menjelaskan pada rapat musyawarah ini pendamping desa bertanya kepada Kepala Desa bahwa pekerjaan HOG istilah yang digunakan pemerintah desa untuk pekerja jalan di desa, ini dimaksudkan pekerjaan tersebuu untuk pekerja harian atau diborong.

Data (12) fungsi kesantunan meminta keterangan "berapa" menjelaskan bahwa pendamping desa meminta jawaban kepada Kepala Desa untuk memastikan untuk berkubik harus memiliki target berapa perkubik sehingga tidak kelebihan untuk kegiatan berkubik.

Data (13) fungsi kesantunan meminta keterangan "kapan" ini menjelaskan bahwa pendamping desa bertanya waktu pelaksanaan pekerjaan kubik akan berangsugn sebab kelapa desa belum memberikan keterangan tentang kegiatan tersebut.

Data (14) fungsi kesantunan meminta keterangan "Siapa" penjelasan ini disampaikan oleh Bapak sekeretaris BPD yang lama untuk meminta keterangan kepada kepala Desa perihal tentang seputar pemilihan BPD yang baru khususnya dalam bidang adat juga meminta gambaran siapa yang menjadi kandidat pada bidang adat.

Data (15) fungsi kesantunan meminta keterangan "dimana” ini diungkapkan oleh bapak sekertaris BPD yang lama tentang masalah kegiatan kubik batu dengan tujuan meminta keterangan kepada kepala desa mengenai hal tersebut. Kelima fungsi kesantunan meminta keterangan pada kegiatan musyawarah di desa Tarohan memiliki ciri merupakan tuturan interogatif yang bersifat menghendaki adanya jawaban dari mitra tutur yaitu kepala desa.

\section{Fungsi meminta alasan pada rapat musyawarah}

Fungsi kesantunan meminta alasan memiliki indikator bersifat meminta alasan dan menggunakan kata tanya "mengapa" dan "kenapa" sebagai penjelas dari fungsi ini. Kegiatan musyawarah yang diaksanakan oleh desa Tarohan dapat ditemukan pada saat Bapak Tumpil selaku panitia pemilihan anggota BPD yang baru memberikan pertanyaan kepada kepala desa mengenai pemakaian mesin untuk jalan produksi dan jalan desa.

Konteks: dalam situasi pertanyaan dari mewakili masyarakat yaitu Bapak Tumpil.

Data 16

Bapak tumpil: kalaupun kita bekerja dengan menggunakan mesin, alangkah baiknya kenapa harus bekerja dua kali ?

Kepala desa: sebenarnya dua pekerjaan ini memerlukan emapat alat mau buat jalan produksi dua alat dan membuat jalan desa dua alat tapi, saya bicarakan dengan operator supya hemat biaya jadi bayar disana dan bayar disini sehingga perencanaan seperti saya sudah berbiacara dengan pendamping jika itu mau disetujui untuk pembuatan jalan produksi sesudah pembersihan kawasan pohon kemudian kita alokasikan kita akan pindahkan alat itu ke jalan desa. (FSMA1)

Penjelasan mengenai fungsi kesantunan meminta alasan pada data (16) yang disampaikan oleh bapak Tumpil memenuhi sebagai fungsi kesantunan meminta alasan kepada mitra tutur yaitu kepala desa untuk tidak mengerjakan pekerjaan dua kali sekaligus karena itu akan memakai tenaga yang berlebihan sehingga bapak Tumpil selaku penutur meminta alasan kepada kepala desa secara santun dengan memakai kata alangkah baiknya kenapa sebagai kata permintaan yang santun kepada yang lebih tinggi tingkat sosialnya. Menurut (Masran, 2018) saat berucap penutur menyatakan tuturannya bukan hanya tujuan petuturannya melainkan maksud dari tuturan tersebut. Karena tuturan yang jelas konteksnya kana tercipat proses komunikasi yang baik.

\section{Fungsi kesantunan meminta pendapat pada rapat musyawarah}

Fungsi ini menggambarkan pendapat atau buah pikiran yang disampaikan oleh penutur kepada mitra tutur secara santun. Kegiatan musyawarah di desa Tarohan dilakukan dengan tujuan pemerintah desa dan masyarakat dapat memberikan pendapat untuk kemajuan desa, dengan bertanya, memberi masukan, dan saran tentunya dengan cara santun ditemukan beberapa fungsi kesantunan meminta pendapat yang dilakukan oleh kepala desa dan pewara.

Konteks: kepala desa meminta pendapat dari masyarakat atas pemilihan bidang adat dan pewara meminta pendapat kepada seluruh masyarakat dalam suasana rapat

\section{Data 17}

Kepala Desa: jadi, kita sepakat kalau bapak Yohanes Mayuntu sekalipun umurnya dia atas 60 Tahun tetap kita pakai saya akan mengeluarkan surat keputusan kepala desa dan lampirannya daftar hadir dan berita acara sehingga jika ada omongan dari diluar kita sudah memiliki bukti dan ini dibahas dalam musyawarah desa jadi bagaimana menurut masyarakat?? (FSMPEN1)

\section{Data 18}

Pewara: sudara-saudaraku, ate tatae memang ke tate??? bagaimana sudah tidak ada pertanyaan saran dan masukan untuk rapat ini karena akan diakhiri? (FSMPEN2)

Fungsi kesantunan meminta pendapat dalam petuturan yang dilakukan oleh kepala desa dan pewara pada data (17) dan (18) menggambarkan konsep meminta pendapat yang ditandai dengan kata "bagaimana" sebagai kata tanya memiliki ciri tuturan interogatif, memberikan keuntungan mitra tutur dan meminimalkan keuntungan penutur pada proses berjalannya rapat musyawarah. 
Data (17) kepala desa ingin meminta pendapat kepada masyarakat pemilihan bapak mayuntu sebagai bidang adat ini akan disetujui oleh pemerintah sekalipun umurnya sudah melebihi aturan tetapi akan dipertanggungjawabkan oleh pemerintah desa.

Data (18) pewara ingin menanyakan bagaimana apakah sudah tidak ada lagi masukan, kritikan dan saran untuk disampaikan kepada pemerintah desa, sehingga pewara meminta pendapat masyarakat untuk menjawab pertanyaan yang diajukan dengan menggunakan bahasa yang santun.

\section{Fungsi kesantunan meminta kesungguhan pada rapat musyawarah}

Fungsi kesantunan meminta kesungguhan memiliki indikator mengiyahkan pendapat dan menggunakan tuturan interogatif disertai kata "bukan" sebagai penegasnya. Ketika pelaksanaan kegiatan musyawarah di desa Tarohan ditemukan beberapa data yang akan menjelaskan fungsi kesantunan meminta kesungguhan yang dipaparkan oleh kepala desa dan pendamping desa.

Konteks: kepala desa sedang membahas mengenai penyelenggaraan dana desa melalui pengecetan pagar desa dan pendamping desa membahas mengenai BPD yang baru)

\section{Data 19}

Kepala Desa: tetapi bukan pemerintah desa tidak memerhatikan tetapi waktu pembuatan pagar itu sudah selesai sehingga akan dibuat bagaimana sudah tidak ada anggaran lagi saya ingin berharap dengan adanya dana ini bisa berkembang lebih bagus. (FSMKE1)

\section{Data 20}

Pendamping Desa: jadi seperti yang sudah dipilih tadi yaitu bidang adat, jadi sudah sah, tetapi penetapan itu bukan hanya pada bidang adat jika boleh lansgung diisi saja, jadi cara melakukannya namanya siapa jadi BPD bagian apa seperti itu sampai pas 5 anggota BPD sehingga kata kesepakatan itu bukan hanya sepakat dalam bidang adat, tetapi pada bidang-bidang yang lain. (FSMKE2)

Penjelasan mengenai kesantunan meminta kesungguhan pada data (19) menjelaskan bahwa kepala desa meminta kepada masyarakat untuk tetap menjaga kekeluargaan dan tidak membenci pemeritah desa karena ada beberapa masyarakat desa belum sempat tersalurkan bantuan pembuatan pagar sehingga ada permintaan kesungguhan kepala desa kepada masyarakat yang bersifat santun dengan menjelaskan hal tersebut dengan menggunakan kata "bukan" pemerintah desa ingin menjelaskan dengan kesungguhan bahwa bukan mereka yang salah, tetapi memang program dari pemerintah yang sudah selesai.

Data (20) pendamping desa menjelaskan bahwa jika sudah memilih anggota pada bidang adat diharapkan pemilihan pada anggota-anggota pada bidang lain pun segera diselenggarakan sehingga bisa ada keputusan dan kesepakatan atas pemilihan anggota BPD yang baru dengan meminta kesungguhan kepada Kepala Desa dan panitia pemilihan anggota BPD secara santun dengan menggunakan kata "bukan" sebagai penegas kalimat yang dituturkan oleh pendamping desa.

\section{Fungsi kesantunan menyuruh pada rapat musywarah}

Fungsi kesantunan menyuruh meiliki tingkat kesopanan yang sama dari kosakata seperti meminta tolong, memohon, mengharapkan, menghimbau, menyuruh, mengajak, menyarankan, dan menganjurkan. Kegiatan musyawarah yang dilaksanakan di desa Tarohan dapat ditemukan beberapa fungsi kesantunan menyuruh yang dilakukan oleh Pendamping desa dan pewara.

Konteks: Pendamping desa memberikan masukan dan saran kepada kepala desa mengenai air bersih dan kebersihan kampung selanjutnya pewara memberikan masukan kepada masyarakat dan ketua dusun untuk mendaftarkan diri sehingga terdaftar menjadi anggota masyarakat desa Tarohan

Data 21

Masukan pendamping desa: Ini yang perlu diingatkan kedepan minimal kita meningkatkan kesempurnaan itu, harapannya desa ini apalagi kita adalah ibu kota kecamatan saya ingin mengingatkan kembali bahwa Pak Kades pernah berbicara begini sya tidak pernah pelihara hewan tetapi dihalaman rumah itu banyak sekali kotoran hewan. Ini ada hal yang akan saya ingatkan kepada kita, yang mempunyai hewan anjing dan hewan babi, sayang meminta tolong dan tolong dengan sangat, hewan tersebut dikandang ataupun diikat, pagi-pagi dari depan jalan sampai belakang jalan dekat Puskesmas beeehh, sudah ada kue donat disitu, roti goreng, kue lapis itu setiap pagi ada bermacam-macam kue seperti itu. (FSMN1)

\section{Data 22}

Saran dari Pendamping desa: Tarohan sudah mulai menikmati air bersih walapun yang lain belum, tapi tolong ingatkan kepada masyarakat yang lain jangan buat kolam di rumah, lihat apa yang terjadi susah sekali menerima aliran air karena ada kolam didalam rumah, dihimbau kepada Pak Kades dan Anggota baru BPD buatlah jadwal sebual sekali air itu dimasukakan kapur rit sebulan sekali. (FSMN2) 
Data 23

Saran dari pewara

Kemudian kedua tolong yang menikah itu melapor sebab ada beberapa yang sudah menikah, tetapi tidak terdaftar di desa, (FSMN3)

Data 24

Saran dari pewara

jadi tolong para kepala-kepala dusun diperhatikan jika masyarakat dusunnya menikah tolong laporkan kepada kami, kepada kepala dusun dan dari bidang pemerintahan tolong dilihat semuanya itu jadi ini diingatkan sehingga kita tahu semua bahawa perlu sekali data penduduk jadi, kedepannya jika ada maslah jangan menuduh kami karena kami sudah memperingatkan agar melapor dan mendaftar sebagi penduduk di tarohan ini. (FSMNE4)

Penjelasan mengenai fungsi kesantunan menyuruh pada kegiatan musyawarah di desa tarohan ternyata terdapat dua data yang dituturkan oleh Pendamping desa dan Pewara. Data (21) menjelaskan masukan dari pendamping untuk pemerintah desa agar tetap menjaga kebersihan desa khususnya para peternak hewan yang ada di desa menyarankan untuk hewan tersebut di kandang atau dikurung untuk menjaga kebersihan desa memakai kalimat meminta tolong dan tolong dengan sangat terdapat kata tolong yang menggambarkan fungsi kesantunan menyuruh tolong yang bersifat santun.

Data (22) mendeskripsikan saran dari pendamping desa yang menyatakan kesantunan menyuruh dengan kata meminta tolong sebagai penanda kesantunan berbahasa dengan tuturan imperatif dengan maksud untuk tidak membuat kolam di rumah para warga karena akan menghambat aliran air dari rumah ke rumah dengan menyertakan sindiran yang membuat tertawa audien yang hadir pada rapat tersebut.

Data (23) pewara menjelaskan bahwa masalah kumpul kebo yang sudah terjadi pada masyarakat desa diharapkan hendak melapor ke desa sehingga akan didaftarkan untuk dinikahkan sehingga pewara memakai kata tolong untuk penanda tuturan imperatif fungsi kesantunan berbahasa menyuruh.

Data (24) pewara menghimbau kepada ketua dusun untuk melaporkan setiap masyarakat yang terlihat tinggal bersama atau kumpul kebo untuk dinikahkan dengan menggunakan kata tolong sebanyak tiga kali untuk mengingakan ketua dusun berserta jajarannya masukan dari pewara sebagai perwakilan pemerintah desa.

Data (21), (22), (23), dan (24) merupakan fungsi kesantunan menyuruh yang bersifat santun karena menjaga hubungan antara penutur dan mitra tutur sebagai suatu keluarga atau ikatan solidaritas antara pemerintah desa dan masyarakat untuk membangun desa yang lebih baik. Menurut (Fauzi \& Islami, 2017) dalam proses tindak tutur kesantunan dianggap penting karena antara penutur dan mitra tutur saling memahami. Artinya antara penutur dan mitra tutur terjadi prinsip kerjasama yang melengkapi prinsip kesantunan.

\section{Fungsi kesantunan melarang pada rapat musyawarah}

Fungsi kesantunan melarang menggambarkan perbuatan yang dilakukan untuk larangan terhadap sesuatu hal dan terdapat penanda mohon sehingga bersifat santun dalam proses petuturan. Kegiatan musyawarah yang dilakukan di desa Tarohan menghasilkan beberapa kata larangan yang disampaikan oleh kepala desa kepada masyarakat.

Konteks: Kepala Desa sedang menjelaskan pertanyaan yang ditanyakan oleh bapak sekretaris BPD yang lama.

\section{Data 25}

Kemudian ada pertanyaan dari Bapak Sekeretaris BPD yang lama tadi, maslah batu, kerikil dan pasir jadi sebelumnya pun sudah dijelaskan oleh Kades yang lama dan bapak sekertaris BPDpun hadir bahwa bisa diambil di pantai pasir dan kerikil terkecuali batu tetapi batu tidak bisa di ambil di wilayah-wilayah pemukiman jika pasir dan kerikil untuk keperluan rumah tangga itu diperbolehkan. Dan saya mohon untuk tidak mengambil batu didekat pemukiman warga harus jauh dari pemukiman masyarakat. (FSML1)

Penjelasan mengenai fungsi kesantunan melarang pada kegiatan musyawarah di desa Tarohan pada data (25) menjelaskan bahwa kepala desa menjawab pertanyaan dari sekretaris BPD yang lama mengenai pengambilan batu untuk kebutuhan material pembangunan desa dengan membahasakan secara santun dengan menyenangkan muka mitra tutur dengan menggunakan kata mohon sebagai penjelas mengenai pertanyaan dari bapak sekretris BPD yang lama dan meminta masyarakat agar tidak membuang sampah sembarangan tempat.

Data (25) menandakan tingkat kesantunan dengan memakai kata "mohon" sebagai tindakan larangan santun yang diungkapkan oleh kepala desa sebagai penutur untuk meminimalkan keuntungan penutur dan memberikan keuntungan kepada mitra tutur.

\section{Fungsi kesantunan meminta maaf pada rapat musyawarah}

Penggunaan kata meminta maaf dalam bahasa Indonesia hanya memakai kata maaf serta penggunaan kata sapaan bapak dan ibu untuk terlihat santun. Tindak tutur maaf memiliki tiga macam yakni tindak tutur maaf yang dilontarkan tanpa basa-basi, tindak tutur maaf yang dilontarkan secara langsung, dan tindak tutur maaf yang tersirat. Kegiatan musyawarah di desa Tarohan hanya terdapat tindak tutur maaf yang dilontarkan tanpa basa-basi yang disampaikan oleh pendamping desa.

Konteks: Permintaan maaf pendamping desa kepada kepala suku) 


\section{Data 26}

Pendamping desa: minta maaf untuk orang tua Ruangan atau Kepala Suku karena sejujurnya adat di desa ini harus perlu di benahi sebagai contoh suku ananoneg (ini adalah slah satau suku yang mendiami tarohan) minta maaf ketua suku anaoneng saya sejujurnya tidak melihat suku ananoneg membuat sekalipun kegiatan apakah suku ini sudah mati atau hidup (dengan nada tertawa) sjeujurnya saya bagian dari suku ini tetapi tidak ada pergerakan! (FSMM1)

Fungsi kesantunan meminta maaf pada kegiatan musyawara di desa Tarohan ini menjelaskan bahwa pada data (26) terdapat dua permintaan maaf tanpa basa-basi yang diucapkan oleh pendamping desa kepada kepala suku dan ketua suku sebagai suatu teguran tetapi menjaga hubungan baik antara penutur (pendamping desa) dan mitra tutur (kepala suku dan ketua suku) dengan menggunakan kata maaf pada awal kalimat dan mempedulikan perasaan mitra tutur dengan cara berbicara secara santun dan jujur.

\section{Fungsi kesantunan mengeritik pada rapat musyawarah}

Kata mengeritik dalam kehidupan sehari-hari pasti diartikan sebagai keburukan, kekurangan, kekeliruan, dan kesalahan orang tetapi, mengkritik dalam peristiwa tuturan akan mengancam muka negatif dari mitra tutur sehingga untuk menghindari hal tersebut dapat menggunakan kata berputar yang akan memberi pengaruh tuturan yang lebih santun. Kegiatan musyawarah yang dilaksanakan di desa Tarohan terdapat beberapa fungsi kesantunan mengeritik yang dituturkan oleh pendamping desa, bapak Tumpil dan Kepala Desa.

Konteks: pendamping desa sedang membicarakan masalah desa Matahit, Bapak Tumpil menjawab pertanyaan dari Bapak Sekretaris BPD yang lama, dan Kepala Desa membahas tentang bidang adat

\section{Data 27}

Pendamping desa : salah satu penyebab desa Matahit sampa hari ini tidak kelar masalahnya karena tidak memiliki tanda tangan ketua BPD ini diberitahukan (kata pemberitahuan) sampai KADES pergi ke provinsi uangnya tidak dicarikan karena tidak ada tanda tangan ketua BPD karena ada persoalan politik disana makanya jika kita ingin membangun kampung dengan memakai urusan politik jangan bermimpi akan selesai dengan benar akan susah skali ujung-ujungnya akan terjadi kekacauan jadi seperti itu, jadi BPD itu akan menjadi orang yang akan mengingatkan dan menegur KADES jika salah, ibarat kata BPD ini sebagai orang tua yang ada dikampung untuk mengingatkan anaknya jika salah jika anak ini tidak mendengarkan tentunya akan diberikan sanksi maka BPD berhak melakukan musyawarah luar biasa untuk mempersoalan itu (FSMG1)

\section{Data 28}

Bapak Tumpil: dan rupanya tadi ada pertanyaan dari bpk Sekertaris BPD yang lalu yang mana siap sebenarnya yang mempunyai nama di bidang adat sedangkan kami sebagai panitia tidak tahu siapa karena harus orang yang menguasai adat secara kesluruahan yang akan menjadi di bidang adat (menimpal pertanyaan dari bapak Sekretaris BPD lama) dan juga tadi sudah dijelaskan oleh Pendamping desa bahwa bidang adat itu sangatlah penting, jika adat berjalan dengan baik akan baik pula desa kita (FSMG2)

\section{Data 29}

Kepala Desa: jadi dalam desa Tarohan, bukan memuji desa saya di Alo (karena KADES dari desa Alo dan menikah dengan istrinya asal Tarohan) di bagian adat berjalan dengan baik dan saya ingin memperjelas lagi jika ingin disepakati saya usulkan satu nama dan saya yakin dengan BPD baru yang akan berbicara dengan pemerintah dan seperti kata bapak Pendamping tadi ruangan ini (adat ini) ini sudah dibicarakan ketika saya menjadi KADES tahun 2017 tapi tidak ditindak lanjuti oleh orang tua adat. (FSMG3)

Fungsi kesantunan mengeritik ini menjelaskan pada data (27) Pendamping desa melakukan kritikan kepada desa Matahit bahwa jangan ada unsur politik dalam membangun suatu desa sehingga tidak akan terjadi perpecahan, dengan penambahanan kalimat yang berputar untuk terlihat santun bahwa pendamping desa menjelaskan ketika ada permasalahan dalam suatu desa tegurlah Kepala desa dan pemerintah desa didalamnya sehingga tidak akan terjadi perpecahan. Data (28) Bapak Tumpil menjawab pertanyaan yang diajukan oleh sekretaris BPD yang lama menyangkut bidang adat, bapak tumpil menjelaskan bahwa mereka sebagai anggota panitiapun belum mengetahui siapa yang dapat dijadikan calon dalam bidang adat karena belum ada yang mendaftar dan tidak ada yang cocok harus mereka yang menguasai bahasa Talaud sebagai kriterianya, tetapi bapak Tumpil memperjelas dengan menggunakan kalimat berputar bahwa jika bidang adat berjalan dengan baik, akan baik pula desa tersebut karena bidang adat sangat penting bagi desa Tarohan untuk melestarikan budaya agar tidak punah. Data (29) Kepala Desa ingin mengeritik bidang ada yang ada di desa Tarohan dan membandingkan dengan desa yang menjadi tempat lahirnya kepala desa, dengan menggunakan kalimat berputar yaitu ini saya sudah bicarakan kepada kepala adat yang ada di Tarohan ini untuk membahas tentang bidang adat dalam BPD, tetapi tidak ditindaklanjuti sehingga Kepala Desa mengeritik pihak adat di Tarohan dan membandingkannya dengan desa Alo. 
Data penelitian (27), (28), dan (29) merupakan fungsi kesantunan mengeritik secara santun karena mempedulikan wajah mitra tutur dengan cara menggunakan kalimat berputar sebagai penanda kesantunan secara simpati. Tuturan yang dituturkan oleh Pendamping desa, Bapak Tumpil, dan Kepala Desa termasuk dalam maxim simpati yang mempedulikan sesama yang harus diterapkan dalam kehidupan sehari-hari sehingga proses petuturan berjalan dengan baik dan terjalin sebuah solidaritas antara penutur dan mitra tutur (Ningrum \& Mulyono, 2017).

\section{PEMBAHASAN}

Fungsi kesantunan berbahasa dilakukan oleh pihak penutur sebagai bentuk tuturan dalam proses petuturan. Pada penelitian ini yang menjadi fokus yakni fungsi kesantunan dalam proses petuturan di kegiatan musyawarah desa Tarohan dengan melibatkan pemerintah desa dan masyarakat desa. Kegiatan musyawarah merupakan kegiatan yang melibatkan banyak orang untuk menemukan solusi dari permasalahan yang di temukan. Hal ini tergambar pada kegiatan musyawarah yang dilakukan di desa Tarohan ditemukan 29 data fungsi kesantunan berbahasa. Akan dipaparkan sebagai berikut.

Pertama, fungsi menyatakan informasi bersifat memberitahukan keadaan terhadap sesuatu hal, informasi merupakan suatu kabar berita, pemberitahuan, penerangan, dan keterangan untuk mengambil keputusan terhadap sesuatu. Informasi yang disampaikan jika tidak mengandung kesantunan akan dianggap tidak santun karena merungikan penutur dan mitra tutur pada proses pertuturan. Terdapat dua data tuturan menyatakan informasi yang disampaikan oleh ketua BPD yang baru yaitu (1) yang sudah diumukan tadi malam dan tadi pagi bahwa pada hari ini kita akan melaksanakan musyawarah desa tentang pelaksanaan dana desa yang akan sudah diterima oleh Pemerintah Desa pada pagi hari ini. (2) dan pada hari ini juga kita akan menetapkan tentang pemilihan BPD yang baru, sebab batas dari kami sebagai BPD, cukup sampai bulan ini. Kedua data ini dapat menggambarkan fungsi menyatakan informasi dengan menggunakan kesantunan langsung yaitu secara langsung menyampaikan informasi karena ketua BPD yang lama memberikan informasi dan kabar berita kepada masyarakat.

Kedua, fungsi menyatakan perjanjian bersifat pernyataan atau persetujuan terhadap suatu hal yang bersifat santun. Terdapat dua data yang dituturkan oleh Pendamping desa dan Kepala Desa yaitu (1) saya setuju dengan pendapat pak Kades tapi saran saja yahh pak Kades. (2) Karena diminggu pertama itu, harus dituntut untuk pelaksanaan pelantikan BPD baru dibulan berikut sehingga petunjuk dari Bapak Camat mengeluarkan surat keputusan kepala Desa walaupun diatas 60 Tahun khususnya bidang Adat dan itu saya sudah komunikasikan dengan BPM. Kedua data tersebut merupakan fungsi kesantunan yang menyatakan perjanjian bersifat pernyataan persetujuan suatu hal.

Ketiga, Fungsi menyatakan keputusan memiliki ciri putusan ketika ada salah satu masyarakat bertanya "jadi dalam setahun itu yah?" dan jawaban dari kepala desa "iya dalam setahun 32 juta". Data tersebut merupakan pengakuan yang sifatnya memberikan jawaban terhadap apa yang ditanyakan sehingga pada kegiatan musyawarah tersebut antara kepala desa dan masyarakat terjalin komunikasi yang baik karena menggunakan kata santun dalam proses petuturan.

Ketujuh, fungsi meminta keterangan memiliki ciri meminta keterangan terhadap sesuatu hal. Terdapat lima data yang ditemukan pada kegiatan musyawarah di desa Tarohan adalah kata tanya "apakah" untuk benda, kata "siapakah" untuk orang, kata tanya "berapa" untuk jumlah, kata tanya "dimanakah" untuk tempat, dan kata tanya "kapan" untuk waktu. Kelima data tersebut ditemukan pada tuturan yang disampaikan oleh Pendamping Desa dan Sekretaris BPD yang lama selama bertutur sehingga kelima data tersebut dapat digolongkan ke dalam fungsi menyatakan keterangan.

Kedelapan, fungsi meminta alasan menggunakan kata tanya "mengapa" dan "kenapa" sebagai penjelas untuk fungsi ini. Pada kegiatan musyawarah di desa Tarohan terdapat satu data saja yaitu kata tanya "kenapa" sebagai pertanyaan dari Bapak Tumpil dengan menggunakan kalimat “alangkah baiknya kenapa harus bekerja dua kali?” data ini dinyatakan sebagai fungsi meminta alasan karena menggunakan kata tanya "kenapa" untuk memperjelas fungsi meminta alasan dalam proses petuturan antara Bapak Tumpil dan Kepala Desa.

Kesembilan, fungsi meminta pendapat mempunyai ciri melontarkan buah pikiran dengan menggunakan kata tanya "bagaimana". Kegiatan musyawarah yang dilaksanakan di desa Tarohan menghasilkan dua data sebagai gambaran mengenai fungsi meminta pendapat yang dituturkan oleh kepala desa dan pewara. Kata yang ditemukan pada tuturan kepala desa yaitu bagaimana menurut masyarakat! Ini merupakan tuturan yang mengandung fungsi meminta pendapat karena menggunakan kata tanya "bagaimana". Kemudian tuturan pewara yaitu bagaimana sudah tidak ada pertanyaan saran dan masukan untuk rapat ini karena akan diakhiri? Tuturan ini juga dikategorikan sebagai fungsi meminta pendapat karena memakai kata tanya "bagaimana" sebagai acuan dalam menentukkan fungsi meminta pendapat.

Kesepuluh, meminta kesungguhan memiliki ciri mengiyahkan pendapat dan mempunyai pemikiran tentang mitra tutur yang sudah diketahui dan memberikan pembenaran untuk penegasan pemikiranna terhadap mitra tutur. Pada kegiatan musyawarah di desa Tarohan ditemukan dua data yang dituturkan oleh kepala desa dan pendamping desa yakni kata "bukan" sebagai penegas untuk permasalahan yang telah dihadapi. Dengan demikian kata "bukan" diidentifikasi sebagai fungsi meminta kesungguhan baik yang dituturkan oleh kepala desa dan pendamping desa pada kegiatan musyawarah tersebut. 
Kesebelas, fungsi kesantunan menyuruh memiliki sifat suruhan, dan memiliki tingkat kesopanan seperti meminta tolong, memohon, mengharapkan dan lain-lain. Dalam kegiatan musyawarah yang dilaksanakan di desa Tarohan terdapat empat data yang ditemukan yang disampaikan oleh pendamping desa dan pewara yaitu kata "harapannya", "meminta tolong dan tolong dengan sangat", "dihimbau". "tolong" dan "tolong, tolong, tolong". Kata-kata yang telah di temukan tersebut merupakan data yang mengambarkan sifat suruhan yang santun yang di ucapkan oleh pendamping desa dan pewara sebagai fungsi kesantunan menyuruh.

Keduabelas, fungsi kesantunan melarang bersifat larangan terhadap sesuatu hal dan penggunaan kosakata yang mengandung kesantunan. Pada kegiatan musyawarah yang di desa Tarohan terdapat satu data yang di temukan tuturan kepala desa yang menggunakan kata "mohon" sebagai fungsi kesantunan melarang yang santun karena memakai kata "mohon" sebagai kata yang mencerminkan kesantunan dengan bersifat larangan, tetapi dengan kata yang santun sehingga tuturan itu terlihat santun karena penggunaannya yang mengandung kesantunan.

Ketigabelas, fungsi kesantunan meminta maaf bersifat melalukan sikap meminta maaf baik penutur maupun mitra tutur dan menggunakan kata kategori fatis seperti "ya" dan kata interjeksi "wah" dan "aduh". Pada kegiatan musyawarah yang diadakan di desa Tarohan ditemukan satu data yang menggambarkan fungsi kesantunan meminta maaf yang dituturkan oleh pendamping desa yang bersifat meminta maaf tanpa basa-basi dengan menggunakan dua kata "maaf" sekaligus dalam proses petuturannya.

Keempatbelas, fungsi kesantunan mengeritik mempunyai ciri mengancam muka mitra tutur, menggunakan kalimat berputar, dan membuat senang perasaan dari mitra tutur. Pada kegiatan musyawarah yang dilaksanakan di desa Tarohan terdapat tiga data dengan ciri-ciri yang sesuai dengan fungsi kesantunan mengeritik yaitu (1) penambahanan kalimat yang berputar untuk terlihat santun bahwa pendamping desa menjelaskan "ketika ada permasalahan dalam suatu desa tegurlah Kepala desa dan pemerintah desa didalamnya sehingga tidak akan terjadi perpecahan" (2) bapak Tumpil memperjelas dengan menggunakan kalimat berputar "bahwa jika bidang adat berjalan dengan baik, akan baik pula desa tersebut karena bidang adat sangat penting bagi desa Tarohan untuk melestarikan budaya agar tidak punah". (3) dengan menggunakan kalimat berputar yaitu ini "saya sudah bicarakan kepada kepala adat yang ada di Tarohan ini untuk membahas tentang bidang adat dalam BPD tetapi tidak ditindaklanjuti sehingga Kepala Desa mengeritik pihak adat di Tarohan dan membandingkannya dengan desa Alo". Ketiga data tersebut terdapat dua ciri yang termasuk dalam fungsi kesantunan mengeritik yaitu menggunakan kalimat berputar dan mengancam muka negatif mitra tutur.

\section{SIMPULAN}

Fungsi kesantunan berbahasa dalam kegiatan musyawarah desa Tarohan ditemukan 14 jenis fungsi kesantunan yaitu fungsi menyatakan informasi memiliki jumlah dua data, fungsi menyatakan perjanjian memiliki dua data, fungsi menyatakan keputusan memiliki dua data, fungsi keterangan memiliki satu data, fungsi selamat memiliki dua data, fungsi meminta pengakuan memiliki satu data, fungsi meminta keterangan memiliki lima data, fungsi meminta alasan memiliki satu data, fungsi meminta pendapat memiliki dua data, fungsi meminta kesungguhan memiliki dua data, fungsi menyuruh memiliki dua data, fungsi melarang memiliki satu data, fungsi meminta maaf memiliki satu data, dan fungsi mengeritik memiliki tiga data.

Berdasarkan simpulan yang telah dipaparkan sebelumnya, terdapat beberapa saran untuk bagian-bagian yang terkait pada penelitian ini. Uraiannya adalah sebagai berikut. Pertama, bidang pendidikan khususnya bidang linguistik diharapkan dapat menambahkan ilmu dalam proses pembelajaran lebih khususnya kesantunan dalam berbahasa untuk kemajuan bidang linguistik yang semakin berkembang seiring berjalannya waktu, dan semakin memperdalam penelitian mengenai linguistik terlebih sosiolinguikstik dalam rana masyarakat untuk mengethaui permasalahan apa yang akan dialami dalam masyarakat pada proses berbahasa. Penelitian ini juga dapat dijadikan rujukan atau acuan untuk proses pembelajaran bidang linguistik untuk para linguis yang belajar tentang bidang linguistik. Kedua, peneliti selanjutnya diharapkan dapat menjadikan penelitian ini sebagai referensi untuk penelitian selanjutnya. Hal tersebut dapat dilakukan dengan cara melengkapi sesuatu yang terlewatkan dari penelitian ini untuk kemudian dijadikan objek penelitan di kesempatan mendatang.

\section{DAFTAR RUJUKAN}

Chaer, A. (2012). Pragmatik. Jakarta: Rineka Cipta.

Ekawati, M. (2018). Kesantunan Semu pada Tindak Tutur Ekspresif Marah Dalam Bahasa Indonesia. Adabiyyāt: Jurnal Bahasa dan Sastra, 1(1), 1-22. https://doi.org/10.14421/ajbs.2017.01101

Fauzi, M., \& Islami, Q. (2017). Analisis Litotes Dalam Drama Macbeth Karya William Shakespeare: Kajian Sosiopragmatik. Jurnal Pustaka Budaya, 4(1), 46-54.

Feeney, A., \& Bonnefon, J. F. (2013). Politeness and Honesty Contribute Additively to the Interpretation of Scalar Expressions. Journal of Language and Social Psychology, 32(2), 181-190. https://doi.org/10.1177/0261927X12456840

Gunawan, F. (2014). Representasi Kesantunan Brown dan Levinson Dalam Wacana Akademik (Brown and Levinson's Politeness Representation in Academic Discourse). KANDAI, 10(1), 16-27.

Locher, M. A. (2006). Polite Behavior within Relational Work: The Discursive Approach to Politeness. Multilingua - Journal of Cross-Cultural and Interlanguage Communication, 25(3), 249-267. https://doi.org/10.1515/MULTI.2006.015 
Masran, S. (2018). Analisis Penggunaan Bahasa pada Papan Iklan di Kuala Lumpur (Kajian Sosiopragmatik). AL-ISHLAH: Jurnal Pendidikan, 10(2), 244-254.

Ningrum, I. W., Andayani., \& Mulyono, S. (2017). Analisis Prinsip Kesantunan Berbahasa pada Kegiatan Diskusi Kelas Siswa SMA Negeri 7 Surakarta. Jurnal BASASTRA, 5(1), 127-143.

Nurjamily, W. O. (2015). Kesantunan Berbahasa Indonesia Dalam Lingkungan Keluarga (Kajian Sosiopragmatik). Jurnal Humanika, 15(3), 18.

Saputry, D. (2016). Strategi Kesantunan Positif dan Negatif Dalam Bentuk Tuturan Direktif di Lingkungan STKIP Muhammadiyah Pringsewu Lampung. Jurnal Pesona, 2(1), 149-160.

Sari, I. R. (2014). Analisis Pragmatik Pelanggaran Tindak Tutur Guru di SMA Lentera. Pena: Jurnal Kajian Bahasa dan Sastra, Wijayanto, A. (2014). Ketidaksantunan Berbahasa: Penggunaan Bahasa Kekerasan di Sinetron Bertema Kehidupan Remaja. Prosiding Seminar Nasional "Ketidaksantunan Berbahasadan Dampaknya dalam Pembentukan Karakter”, $115-125$. 